\title{
Mechanism of Cell Growth Inhibition by Menadione
}

\author{
Seung Wook Ham, Soomee Jin, and Jeung Hwan Song \\ Deparment of Chemistr. Chang-ing Linersity, Seom 156-756. Aored \\ Receivedilprit 23, 2002
}

Key Words : Menadione, l'hosphatase

Vitamin $\mathrm{K}_{3}$ (menadione) and synthetic vitamin $\mathrm{K}$ analogues live attracted attention because of their significant anticancer.' Recent study has shown that menadione treatment causes cells to arrest in $\mathrm{G}_{1}$, and its mechanism of in cell growth inhibition has been suggested by the generation of superoxide. ${ }^{2}$ However, it was reported that superoxide dismutase did not antagonize the growth induibitory effects of menadione ${ }^{3}$ and the toxic oxygen species. inducing most of the DNA breakages in menadione-treated cells were not responsible for menadione s toxicity: ${ }^{+}$ln the previous study: we have proposed altemative mechamism of $G_{\text {] }}$ arrest where menadione inactivates cdc25A phosphatase," sulfhydryldependent protein. which is presumed to promote entry into $\mathrm{S}$ phase by acting on cdk." Recently, the binding of menadione to the active site of the enzyme was also proven by incubating |methyl- ${ }^{3} \mathrm{H} \mid-$ menadione with the catalytic domain of cdc $25 \mathrm{~A}$ phosphatase. However, it was found that menadione also inactivated cdc25B and $-\mathrm{C}^{8}$ which are most1y expressed in $\mathrm{G}_{2}-\mathrm{M}^{9}$ These observations make it unclear whether the action of cell growth inhibition at $G_{1}$ phase simply arises from the inhibition of cdc25A phosphatase or oxidative stress

ln previous study. we showed that MKP-l. dual-specificity phosphatase. which mediates dephosphorylation of MAP, was inactivated by menadione. "' Since MAP kinase is capable of phosphorylating p53 at threonine 73 and $83^{11}$ and activation of p53 through phosphorylation can lead to the transcriptional upregulation of the cyclin-dependent kinase inhibitor. p21, it was proposed that the inhibitory action of p2l on cdk by MAP kinase activation might result in cell cycle arrest at $\mathrm{G}_{1}$ phase. ${ }^{\text {I? }}$

To demonstrate this hypothesis. logarithmically growing lnuman hepatocarcinoma SK-Hep-I cells were first incubated with $100 \mu \mathrm{M}$ of menadione for a period of 6,12 . or $2+\mathrm{h}$. Cells were then harvested and soluble extracts were assayed for the expression levels of p53 using p53 monoclonal antibody. Interestingly. as shown in Figure 1 (lane 1). Western blotting showed that similar amounts of $\mathrm{p} 53$ were recovered in immunoprecipitates from menadione-treated and non-treated cells. In conjunction with the earlier observation that the amount of p53 protein increases in response to a variety of signals including DNA-damaging agents through the production of reactive oxygen species (ROS).$^{1.3}$

"Comesponding author. phone: +82-2-820-5203: Fax: +82-2-8254736: e-maij: subamíf $f$ caulac.kT
(A)

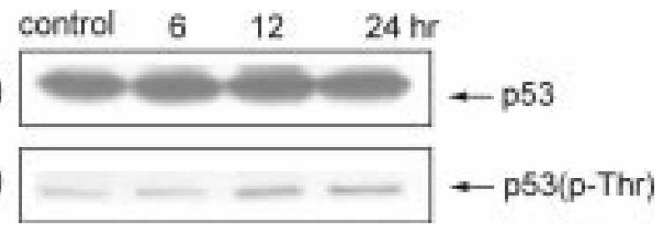

Figure 1. Eflects of menedione on expression and phosphor lation kwel of p53 in SK-hep-l cells. I luman hepatocarcinoma SK-I lep-I cells were grown in RPMT 1640 medium supplemented with $10 \%$ heat-inactivated fetal bovine setum and antibiotics ( 100 units/ml. penicillin and $100 \mathrm{mg} / \mathrm{mL}$ streptomycin) at $37^{\circ} \mathrm{C}$ in $5 \% \quad \mathrm{CO}_{2}$ humidiliod incubator. Cells were plated at a density of $3 \times 10 \% / \mathrm{mL}$ on a culture dish. Cells with or without $100 \mu \mathrm{M}$ water soluble menadione (Sigma) were washed with PBS and lysed in IF.NS bullur $(50 \mathrm{mM}$ Tris-H ICl, $2 \mathrm{mM}$ LiDlA, $100 \mathrm{mM} \mathrm{NaC1}, 1 \%$ Nonidet P-40, $1 \mathrm{mM}$ phenylmethylsulionyl lluride, pH 7.5 ). For Westem blot protein extracts ( $100 \mu \mathrm{g}$ ) were separated on $12 \%$ SDS-PNGF. and electrotransfetred to the PVDF transfer membrane (Schleicher and Schuell). (A) the blot was incubated with anti-p53 monoclonal (Santa Cruz Biolechnology) for $15 \mathrm{~h}$, Followed by horseradish peroxidase labeled secondary antibody (Amersham) for $2 \mathrm{~h}$, and then developed by the enhanced-chemiluminescence (F.C.I.) detection kit (Amersham). (B) The ly seles were immunoprecipited with anti-p53 antibody Followed by Westen bloting with phosphothreonine antibody (7vmed)

our results show that enzymatic redox cycling does not play a critical role in menadione-induced cell cycle arrest.

To determine whether MAP kinase was activated wio hyperphosphorylation, the extracts of menadione-treated cells were also immunoprecipitated with anti-MAP kinase antibody and anti-phospho-MAP kinase antibody. The results shown in Figure 2 (lane 1 and 2) demonstrate that the intensity of phosphory larion of the MAP kinase was increased. The activities of MAP kinase were also assayed using myelin basic protein (MBP) as a substrate. When proteins were resolved by SDS polyacrylamide gel electrophoresis. the results presented in Figure 2 (lane 3) show that MAP kinase was activated by treatment of the cell with menadione.

We next evaluated whether activation of MAP kinase was necessary for the activation of p53. although menadione was proved to have no effect on p53 induction. To detect the phosphorylation level of threonine, p53 was immunoprecipitated with anti-p53 antibody from the cell extracts. and immunoblotted with anti-phosphothreonine antibody. As shown in Figure 1 (lane 2), the results correlated with the hyperphosphorylation status of $\mathrm{p}^{3} 3$ in menadione-treated 


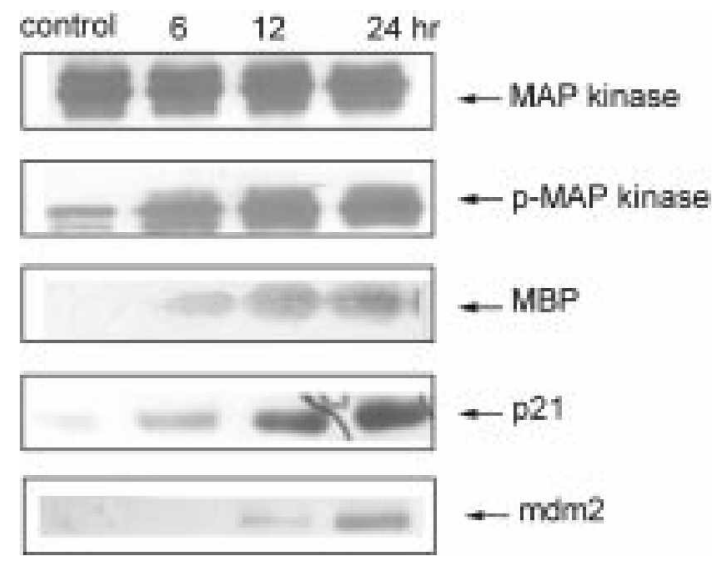

Figure 2. Lillects of mentadione on MAP kinase activity and expression level of p2l and mdm2 in SK-hep-l cells. The blot was incubated with monoclonal antibodies such as anti-M $A P$ kinase: -phospho-MAP kinase, -p2I, and -1ndm2 (Santa Cru/. Biotechnologv). lor MAP kinase assay. the lystes ( $10 \mathrm{Hg}$ tolal proteins) were suspended in kinlase bulfer (50) $\mathrm{mM}$ Tris-IiCl. $25 \mathrm{mM} \mathrm{MgCl}$, I mM EDTA, I ImM EGTA 1 1mM DTT, pH 7.4) with 20 mM ATP, 1 $\mathrm{mCi}\left\lceil \%^{32} \mathrm{P}\right\rceil \Lambda \mathrm{TP}$, and $0.5 \mathrm{mg} / \mathrm{mI}$, myelin basic protein (Sigma). Alter 30 min at $30^{\circ} \mathrm{C}$. the reaction was taninated by $10 \mathrm{~mL}$ of $5 \times$ Laminis sample buller. 'lhe proteins were resolved by elatrophoresis on $12 \%$ SDS-PACiF, followed by autoradiography to visualize the phosphorylated nyyelin basic protein.

cells. Since active $p 53$ turns on the transcription of one of its downstream genes, p2 $1^{11}$. p21 was also immunoblotted with p2l monoclonal antibody. Figure 2 (lane + ) showed that prolonged incubation with menadione increased the level of p2l. suggesting that menadione can activate p53 in wivo. However, it has also been reported that oxidative stress can lead to activate $\mathrm{p} 2 \mathrm{l}$ expression in the $\mathrm{p} 53$-independent pathway. In order to rule out this pathway and further confirm that p53 activity was increased in the presence of menadione. the expression of other p53 downstream effector. mdm2. was also examined. In Figure 2 (lane 5), we showed that p53 stimulated mdm2 expression with treatment of menadione. Taking all of these results together, we could conclude that the activity of p53 might be increased by: hyperphosphorylation of MAP kinase.

p53 is also dephosphorylated by multiple protein-serine/ threonine phosphatases such as $\mathrm{PPI}$ and PP2A. ${ }^{17}$ Therefore. we tested whether or not menadione affected these enzymes and found that they were not inactivated by it up to $50 \mu \mathrm{M}$ (data not shown). Moreover. menadione showed no inactivation of the protein tyrosine phosphatases, such as LAR, PTPIB. and Yersinia PTP (data not shown).

The results reported here show that enzymatic redox cycling does not play a critical role in menadione-induced cell cycle arrest in cells, while inactivation of dual-specificity phosphatases is likely to be menadione's primary mechanism of action.

\section{References}

1. (a) Chlebowski. R. T:: Dietrich. M.: Akman. S.: Block. J. B. ('ancer Treat Rep, 1985. 69. 527-532. (b) Noto. V.: 'Taper. H. S.: Jiang. Y. H.: Janssens. J.: Bonte. J.: De Lenecker. W. Cancer 1989. 63. 901-906. (c) Tetet, M.: Margolin. K.: Ahn, C.: Akman. S.: Chow: W.: I contg. W.: Morgan. B. J., Ir.: Raschto. J.: Somlo. G.: Doroshow, I. II Inest, New Dnigs 1995, 13, 157-162. (d) Wang. Z.: Wang. M.: Finn. F.: Carr. B. 1. Hepatology 1995. 22. 876-882.

2. Jacinta. A.: O'Brien. F.: Dawes. I. W. J. Biol Chem. 1998. 273. 8564-8571.

3. Nishikawa. Y: Carr, B. I.: Wang. M.: Kar. S.: Finn. F.: Dowd. P.: 7.heng. 7.. B.: Kems. J.: Naganathan. S. J. Biol. Chem. 1995, 270. $28.304-28.310$

4. Cantoni. O.: Fiorani. M.: Caltabeni. F.: Bellomo. G. Biochem. Pharmacol 42(Suppl.). \$220-\$222

5. Ham. S. W.: l'ark. H. J.: Lim. D. H. Biong. (hem 1997. 25. 3336.

6. Galationot, K.: Bcach. D. Ce/l 1991, 67. 1181-1194

7. Wu, F. Y.-II.: Sun. T.-P. Eur: J. Cancer 1999, 35, 1.388-1.393.

8. Ham. S. W.: l'ark. J.: Kim. H. I.: Song J. H.: Bae. J. Y.: Cho. S.-H. Bull Kowen (them. Soc 2000. 21. 35-36.

9. (a) Miller. J. B. A.: Blevitt. J.: Gerace. L.: Sudhu. K.: Featherstonc. C.: Russell. P. Proc. Aall .tcad Sci. L. S. .t. 1991. 88, 10500-10504. (b) Kumagai. A.: Dunphr, W. Cell 1992, 1.39151

10. Ham. S. W.: Song. I. H.: Kim. H. I.: Jin. S. Bull korean Chem. Soc. 2000. 21.1173-1174.

11. Wang. W. M.: Zhai. Y.: Ferrell. J. E.. Jr. J. Cell Biol. 1997. /37. $422-443$

12. Agarwal. M. I..: Tayler. W. R.: Chemor, M. V.: Chemora. O. B.: Stark, C. R. J. Biol C $/$ km 1998. 273. 1-1

13. (a) Tishler. R. B.: Calderwood. S. K.: Coleman. C. N.: Price. B. D. Cancer Res. 1993. 53. 2212-2216. (b) Ngo. E. O.: Nutler. L. M. Sura. T.: Gutienez. P. L. Res. Toxical. 1998. 11. 360-368.

14. Milczarek, G. J.: Martinez. I.: Bowden. G. T. Life Sci. 1997. 60, I11 